\title{
ОЦІНКА ПОКАЗНИКІВ ЛАТЕНТНОГО ПЕРІОДУ БУЛЬБОКАВЕРНОЗНОГО РЕФЛЕКСУ ТА ЕЛЕКТРОМІОГРАФІЇ В ДІАГНОСТИЦІ ТА ЛІКУВАННІ ХВОРИХ ІЗ ПІДВИЩЕНИМ ТОНУСОМ НЕРВОВО-М'ЯЗОВИХ СТРУКТУР СЕЧОВОГО МІХУРА ТА ДИСТАЛЬНИХ ВІДДІЛІВ ТОВСТОЇ КИШКИ ЗА ГІПЕРКІНЕТИЧНИМ ТИПОМ
}

\author{
${ }^{1}$ ДУ «Інститут урології НАМН України», м. Київ, Україна \\ ${ }^{2}$ Національний медичний університет імені О.О. Богомольця, м. Київ, Україна \\ 3КНП «Центр первинної медико-санітарної допомоги № 2» Солом'янського району, м. Київ, Україна
}

\begin{abstract}
Мета: підвищити ефективність діагностики та лікування хворих із підвищеним тонусом нервово-м'язових структур сечового міхура та дистальних відділів товстої кишки за гіперкінетичним типом.

Матеріали і методи. В групу дослідження увійшло 33 особи 3 поєднаною нейрогенною патологією нижніх відділів сечовивідної системи і нижніх відділів товстої кишки. Діагностику функціональних порушень сечового міхура та товстої кишки проводили з визначенням латентного періоду бульбокавернозного ресрлексу під контролем електроміограсрії.

Результати. Проведені дослідження дозволили оцінити показники латентного періоду бульбокавернозного рефрлексу і електроміографрії в діагностиці хворих із підвищеним тонусом нервово-м'язових структур сечового міхура і дистальних відділів товстої кишки за гіперкінетичним типом. Дані електроміографрічних досліджень дозволили розробити і оптимізувати методи лікування залежно від тонусу нервово-м'язових структур нижніх сечових шляхів і дистальних відділів товстої кишки.

Висновки. Проведене консервативне лікування пацієнтів із підвищеним тонусом нервово-м'язових структур сечового міхура і дистальних відділів товстої кишки за гіперкінетичним типом шляхом електростимуляції за гальмівною методикою $є$ ефективним, забезпечує позитивний ефект в 91,4 \% випадків.
\end{abstract}

КЛЮЧОВІ СЛОВА: нейрогенні розлади сечовипускання; нейрогенна диссункція кишечника; детрузор; урофлоуметрія; електроміографія; бульбокавернозний рефлекс.

Нейрогенні розлади сечовипускання часто спостерігають в урологічній практиці. У третини з них виявляли порушення фрункції нижніх відділів товстої кишки нейрогенного генезу. На даний момент немає чітко сформульованого оптимально необхідного комплексу діагностичних методів для обстеження пацієнтів із вказаною патологією [1-3, 6]. Для успішного лікування поєднаної патології сечовивідної системи і нижніх відділів товстої кишки важливо уточнити причини, виконати ряд клінічних та функціональних досліджень прямої кишки, сечового міхура та їх замикального апарату. Тільки на основі такого обстеження можна надалі планувати тактику лікування і прогнозувати його успішність $[4,5]$.

Мета дослідження: підвищити ефективність діагностики та лікування хворих із підвищеним тонусом нервово-м'язових структур сечового міхура та дистальних відділів товстої кишки за гіперкінетичним типом.
Матеріали і методи. Всі хворі на поєднану нейрогенну патологію нижніх відділів сечовивідної системи і нижніх відділів товстої кишки проходили комплексне обстеження 3 використанням як загальноприйнятих, так і спеціальних методів діагностики.

Діагностику фрункціональних порушень сечового міхура та товстої кишки проводили з визначенням латентного періоду бульбокавернозного реслексу (ЛП БКР) під контролем електроміографії (ЕМГ). Електроміографрія - це графічна та цифрова реєстрація біоелектричної активності м'язів, використовується для якісної і кількісної оцінки функції м'язів, які забезпечують динамічну активність нижніх сечових шляхів. Для цього ми використовували ЕМГ сечового міхура і сорінктерного апарату, анального сорінктера, м'язів тазового дна. Для підсилення біоелектричної активності м'язів нижніх відділів сечової системи та дистальних відділів 
товстої кишки використовували електроміографр 4-канальний фрірми «Медікор» (Угорщина).

Кількісну оцінку функції м'язів, за даними ЕМГ, здійснювали за показниками середнього значення сумарної біоелектричної активності та частотою проходження імпульсів.

Для тестування фрункції спінальних сегментів S2-S4, афрерентних та ефрерентних волокон соромітного нерва, який іннервує сечостатеві органи, вивчали бульбокавернозний рефлекс.

Для запису ЕМГ при проведенні БКР використовували електроміографр «Медікор М-440». За допомогою цього апарату проведено такі методи досліджень: визначення потенціалу дії БКР у спокою $з$ метою виключення змін у досліджуваному м'язі, далі визначали безпосередньо БКР, а потім вимірювали латентний період ЛП БКР.

У нашій методиці лікування використовували зовнішню електростимуляцію сечового міхура, метою застосування якої була переважна дія на детрузор, товсту кишку та їх сорінктерний апарат за гальмівною методикою.

Ефективність лікування ми оцінювали після першого, третього та шостого курсів лікування, в результаті якого ми отримали наступні дані.

Результати дослідження та їх обговорення. До групи дослідження увійшло 33 чоловіки, середній вік яких склав $(42,7 \pm 2,2)$ року, тривалість захворювання у них становила $(13,4 \pm 1,2)$ місяця. У хворих цієї групи середній показник полакіурії до лікування склав $(19,3 \pm 1,7)$ раза, ніктурії - $(3,4 \pm 0,2)$ раза на добу, імперативні поклики склали $(4,9 \pm 0,2)$ раза на добу, а імперативне нетримання сечі спостерігали $(3,4 \pm 0,1)$ раза на добу. Оцінка за опитувальником РРВС склала $(4,6 \pm 0,2)$ бала.

При оцінюванні симптомів клінічних проявів патології дистальних відділів товстої кишки учоловіків до лікування ми спостерігали наступне: запор спостерігалиухворих $(1,8 \pm 0,1)$ раза, нетримання газів$(2,9 \pm 0,2)$ раза, нетримання рідкого калу в пацієнтів - $(1,5 \pm 0,1)$ раза, нетримання твердого калу в чоловіків - $(1,2 \pm 0,1)$ раза. При оцінюванні за опитувальником CRADI-8 у цієї групи хворих до лікування ми отримали $(15,5 \pm 1,3)$ бала.

При проведенні електроміографрічного дослідження м'язових структур сечового міхура та товстої кишки ми отримали середнє значення різниці біопотенціалів детрузора - $(47,8 \pm 2,3)$ мкВ, стінки товстої кишки - $(65,2 \pm 2,8)$ мкВ, на внутрішньому сорінктері сечового міхура - $(43,7 \pm 2,2)$ мкВ, на зовнішньому сорінктері - $(64,6 \pm 2,4)$ мкВ. При оцінюванні тонусу сорінктерного апарату товстої кишки ми спостерігали на внутрішньому сорінктері $(65,4 \pm 2,6)$ мкВ, а на зовнішньому сорінктері - $(89,8 \pm 3,9)$ мкВ.

Оцінка латентного періоду бульбокавернозного рефрлексу в хворих цієї групи склала $(32,6 \pm 2,7)$ м/с.

Після першого курсу лікування показники ЕМГ: детрузора - $(44,7 \pm 1,9)$ мкВ, де покращення склало
$6,9 \%$ ( $>0,2)$, стінки товстої кишки - $(64,2 \pm 2,9)$ мкВ, $1,6 \%$ ( $>0,2)$, на внутрішньому сфрінктері сечового міхура - $(41,4 \pm 1,9)$ мкB, 5,6 \% ( $<<0,001)$, на зовнішньому сорінктері - $(62,9 \pm 2,8)$ мкB, 2,7 \% (p>0,2), на внутрішньому сорінктері - $(63,9 \pm 2,5)$ мкВ, $2,3 \%$ ( $>>0,2)$, на зовнішньому сфрінктері - $(87,3 \pm 3,3)$ мкВ, 2,9 \% (р>0,2) відповідно.

При оцінюванні змін ЛП БКР ми отримали середнє значення, яке склало $(34,4 \pm 2,5) \mathrm{M} / \mathrm{c}$, що відповідає змінам на 5,2 \% (p>0,2).

За результатами третього курсу лікування ми отримали різницю біопотенціалів детрузора $(41,3 \pm 1,9)$ мкВ, де покращення склало 15,7 \% $(p<0,05)$, стінки товстої кишки - $(62,1 \pm 2,6)$ мкВ, $4,5 \%$ ( $>0,2)$, на внутрішньому сорінктері сечового міхура - $(39,2 \pm 2,2)$ мкВ, $11,5 \%(p<0,2)$, на зовнішньому сорінктері - $(61,1 \pm 2,5)$ мкВ, 5,7 \% (p>0,2). При оцінюванні сорінктерного апарату товстої кишки ми спостерігали на внутрішньому сфрінктері $(60,3 \pm 3,1)$ мкВ, 8,5 \% ( $>>0,2)$, а на зовнішньому сорінктері - $(84,5 \pm 2,8)$ мкВ, 6,3 \% (p>0,2) відповідно.

Середнє значення ЛП БКР склало $(35,7 \pm 2,6)$ м/с, що відповідає змінам на 8,7 \% ( $>>0,2)$.

Після завершення 6 курсів лікування у хворих цієї групи ми спостерігали значне поліпшення стану здоров'я: полакіурія зменшилась до $(9,9 \pm 1,1)$ раза на день 95,9\% $\%(p<0,001)$, ніктурія $(1,8 \pm 0,06)$ раза, 88,9 \% ( $p<0,001)$, імперативні поклики зменшились до $(2,6 \pm 0,1)$ раза на добу, 88,5 \% $(p<0,001)$, нетримання сечі - на $(1,9 \pm 0,1)$ раза, 79 \% ( $<<0,001)$. Це також підтверджують результати за опитувальником РРВС, що склало $(2,5 \pm 0,1)$ бала, $84 \%(p<0,001)$.

У хворих цієї групи також спостерігали зменшення кількості запорів до $(1,01 \pm 0,01)$ раза, 78,2 \% $(p<0,001)$, нетримання газів - до $(1,5 \pm 0,1)$ раза, 93,4 \% ( $<<0,001)$, нетримання рідкого калу у пацієнтів цієї групи - до $(0,9 \pm 0,01)$ раза, 66,7 \% $(p<0,001)$, нетримання твердого калу у чоловіків $(0,65 \pm 0,01)$ раза, 84,6 \% (p<0,001). При оцінюванні за опитувальником CRADI-8 ми отримали зменшення до $(8,2 \pm 1,1)$ бала, $89 \%(p<0,001)$.

Різниця біопотенціалів м'язових структур сечового міхура та товстої кишки була наступною: детрузора - $(38,2 \pm 1,9)$ мкВ, де покращення склало $25,1 \%$ $(p<0,01)$, стінки товстої кишки - $(60,8 \pm 2,1)$ мкВ, 7,2 \% ( $<<0,001)$, на внутрішньому сорінктері сечового міхура - $(34,7 \pm 1,9)$ мкВ, 25,9 \% $(p<0,01)$, на зовнішньому сорінктері - $(59,3 \pm 1,1)$ мкВ, 8,3 \% ( $p<0,001)$. При оцінюванні сорінктерного апарату товстої кишки ми спостерігали на внутрішньому сорінктері $(58,4 \pm 2,3)$ мкB, $12 \%(p<0,001)$, а на зовнішньому сорінктері - $(78,7 \pm 2,4)$ мкВ, 14,1 \% $(p<0,05)$ відповідно. Динаміку змін показників електроміографії у чоловіків після першого та після шостого курсів лікування наведено на рисунку 1.

Середнє значення ЛП БКР склало $(37,8 \pm 2,8)$ м/с, що відповідає змінам на 13,8 \% (p<0,05). 


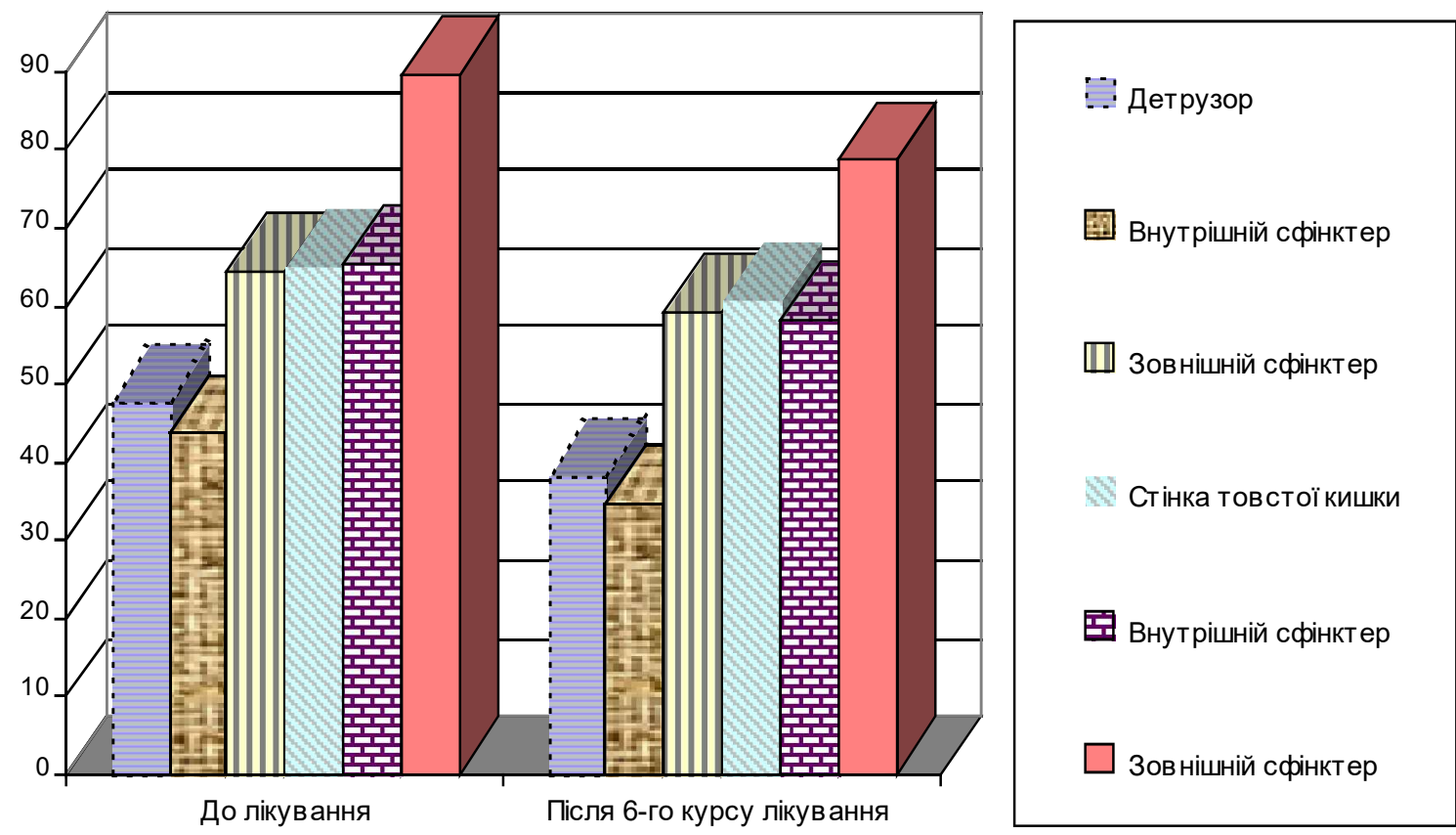

Puc. 1. Динаміка змін показників електроміографії в чоловіків у результаті лікування (мкВ).

У цій групі досліджували 37 жінок, середній вік яких склав $(44,5 \pm 2,3)$ року, тривалість захворювання - $(16,7 \pm 1,6)$ місяця.

Середній показник полакіурії у цієї групи пацієнток до лікування склав $(17,8 \pm 1,5)$ раза, ніктурії - $(4,4 \pm 0,5)$ раза на добу, імперативні поклики склали $(5,6 \pm 0,4)$ раза на добу, а імперативне нетримання сечі спостерігали $(3,6 \pm 0,4)$ раза на добу. Оцінка за опитувальником РРВС склала $(4,9 \pm 0,5)$ бала.

Як показали результати оцінювання симптомів клінічних проявів патології дистальних відділів товстої кишки у жінок до лікування, запор відзначали у хворих $(2,1 \pm 0,2)$ раза, нетримання газів - $(3,4 \pm 0,2)$ раза, нетримання рідкого калу - $(1,8 \pm 0,2)$ раза, нетримання твердого калу - $(1,6 \pm 0,1)$ раза. При оцінюванні за опитувальником CRADI-8 у цієї групи хворих до лікування ми отримали $(16,4 \pm 0,2)$ бала.

Обстежуючи м'язові структури сечового міхура та товстої кишки за допомогою ЕМГ визначили середнє значення різниці біопотенціалів детрузора - $(49,1 \pm 2,9)$ мкВ, стінки товстої кишки $(62,5 \pm 2,1)$ мкВ, на внутрішньому сорінктері сечового міхура - $(44,2 \pm 2,4)$ мкВ, на зовнішньому сорінктері $(63,1 \pm 2,7)$ мкВ. При оцінюванні сорінктерного апарату товстої кишки ми спостерігали на внутрішньому сорінктері $(55,3 \pm 1,5)$ мкВ, а на зовнішньому сорінктері - $(71,2 \pm 2,8)$ мкВ.

Проводячи дослідження бульбокавернозного рефрлексу, а саме його латентний період, у хворих цієї групи, отримано середнє значення $(32,7 \pm 1,4) \mathrm{m} / \mathrm{c}$.

Після першого курсу лікування показники ЕМГ м'язових структур сечового міхура та товстої кишки змінювались наступним чином: середнє значення різниці біопотенціалів детрузора $(42,5 \pm 2,5)$ мкВ, де покращення склало 15,5\% $(p<0,1)$, стінки товстої кишки - $(59,3 \pm 2,3)$ мкВ, 5,4 \% ( $>0,2)$, навнутрішньому сорінктері сечового міхура$(36,7 \pm 1,9)$ мкВ, 20,4 \% (p<0,05), на зовнішньому сорінктері - $(56,3 \pm 2,4)$ мкВ, $12 \%(p<0,1)$. При оцінюванні сорінктерного апарату товстої кишки ми спостерігали на внутрішньому сорінктері $(54,1 \pm 2,1)$ мкВ, 2,2 \% ( $>0,2)$, а на зовнішньому сорінктері - $(69,1 \pm 2,7)$ мкВ, $3 \%$ (p>0,2) відповідно.

Середнє значення ЛП БКР склало $(32,7 \pm 1,4)$ м/с, що відповідає змінам на 4,6 \% ( $p>0,2)$.

Різниця біопотенціалів м'язових структур сечового міхура та товстої кишки після третього курсу лікування становила: детрузора - $(38,1 \pm 2,6)$ мкВ, де покращення склало 28,9\% $(p<0,01)$, стінки товстої кишки - $(58,2 \pm 2,1)$ мкВ, 7,4 \% $(p<0,01)$, на внутрішньому сорінктері сечового міхура $(35,3 \pm 1,9)$ мкB, 25,2 \% $(p<0,01)$, на зовнішньому сорінктері - $(50,6 \pm 2,2)$ мкВ, 24,7 \% ( $<<0,001)$. При оцінюванні сорінктерного апарату товстої кишки ми спостерігали на внутрішньому сорінктері $(52,2 \pm 1,9)$ мкВ, 5,9 \% ( $>>0,2)$, а на зовнішньому сорінктері - $(67,3 \pm 2,5)$ мкВ, 5,8 \% (p>0,2) відповідно. Середнє значення ЛП БКР склало $(34,5 \pm 1,5)$ м/с, що відповідає змінам на 9,6\% $(\mathrm{p}<0,2)$.

Після завершення шостого курсу лікування хворих цієї групи ми спостерігали значне покращення як клінічних, так і результатів ЕМГ. Ми зафріксували, що полакіурія зменшилась до $(9,2 \pm 0,8)$ раза на день, 93,5 \% $(p<0,05)$, ніктурія - $(2,3 \pm 0,1)$ раза, 91,3 \% ( $<<0,001)$, імперативні поклики зменшились до $(2,9 \pm 0,1)$ раза 
на добу, 93,1 \% $(p<0,05)$, нетримання сечі на $(1,9 \pm 0,1)$ раза, $89,5 \%(p<0,05)$.

що стосується оцінки ефективності лікування на основі опитувальника РРВС, то покращення склало $(2,6 \pm 0,1)$ бала, 88,5 \% $(p<0,001)$.

Відносно симптомів дистальних відділів товстої кишки у хворих цієї групи ми відзначали, що кількість запорів зменшилась до $(1,1 \pm 0,1)$ раза, $90,9 \%$ $(p<0,001)$, нетримання газів - до $(1,8 \pm 0,1)$ раза, $88,9 \%(p<0,001)$, нетримання рідкого калу у пацієнтів цієї групи - до $(1,0 \pm 0,1)$ раза, $80 \%$ $(p<0,05)$, нетримання твердого калу у чоловіків $(0,9 \pm 0,01)$ раза, $77,8 \%(p<0,05)$. При оцінюванні за опитувальником CRADI-8 ми отримали зменшення до $(8,9 \pm 0,1)$ бала, $84,3 \%(p<0,05)$.
Різниця біопотенціалів м'язових структур сечового міхура та товстої кишки склала: детрузора $(34,7 \pm 1,2)$ мкВ, де покращення склало $41,5 \%$ $(p<0,001)$, стінки товстої кишки - $(55,6 \pm 2,1)$ мкВ, $12,4 \%(p<0,05)$, на внутрішньому сфрінктері сечового міхура - $(31,4 \pm 1,7)$ мкB, 40,8 \% $(p<0,001)$, на зовнішньому сорінктері - $(45,8 \pm 2,5)$ мкВ, 37,8\% $(p<0,001)$. При оцінюванні ссрінктерного апарату товстої кишки ми спостерігали на внутрішньому сорінктері $(49,2 \pm 2,1)$ мкВ, $12,4 \%(p<0,05)$, а на зовнішньому сорінктері - $(64,1 \pm 2,1)$ мкВ, $11 \%$ $(p<0,05)$ відповідно. Динаміку змін показників електроміографрії у жінок після першого та після шостого курсів лікування наведено на рисунку 2.

Середній показник лП БКР склав $(36,8 \pm 1,6)$ м/с, що відповідає змінам на 15,2 \% $(p<0,05)$.

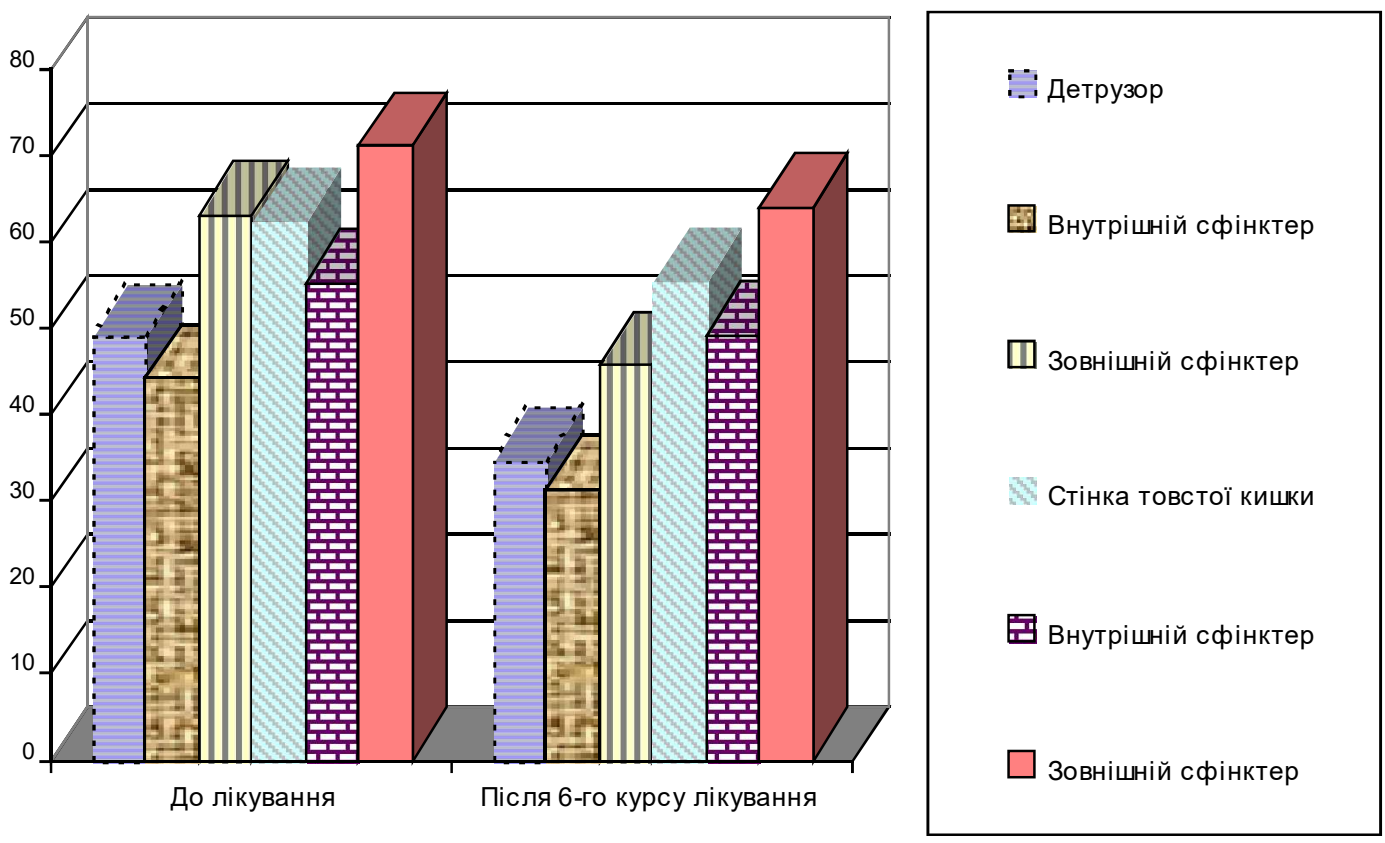

Рuc. 2. Динаміка змін показників електроміографії в жінок у результаті лікування (мкВ).

\section{Висновки}

1. Показники латентного періоду бульбокавернозного рефрлексу та електроміографрії відображають фрункціональний стан нижніх сечовивідних шляхів і дистальних відділів товстої кишки, є об'єктивним критерієм для діагностики.

2. Дані показники латентного періоду бульбокавернозного рефлексу та електроміографрії дозво лили розробити та оптимізувати методи лікування залежно від стану тонусу нервово-м'язових структур нижніх сечових шляхів та дистальних відділів товстої кишки.

Перспективи подальших досліджень полягають у активному впровадженні запропонованої методики лікування.

\section{Список літератури}

1. Bladder and bowel symptoms among adults presenting with low back pain to an academic chiropractic clinic: results of a preliminary study / A. L. Walden, S. A. Salsbury, W. R. Reed, D. J. Lawrence // Journal of Chiropractic Medicine. - 2014. Vol. 13, No. 3. - P. 178-187.

2. Diagnosis and treatment of overactive bladder (non-neurogenic) in adults: AUA/SUFU Guideline / E. A. Gormley, D. J. Lightner, K. L. Burgio[et al.] // The Journal of Urology. - 2012. - Vol. 188, Issue 6, Supplement. - P. $2455-2463$.

3. Diagnosis and treatment of overactive bladder (non-neurogenic) in adults: AUA/SUFU Guideline Amendment / E. A. Gormley, D. J. Lightner, M. Faraday, S. P. Vasavada // The Journal of Urology. - 2015. - Vol. 193, Issue 5. P. 1572-1580.

4. Does the imprecise definition of overactive bladder serve commercial rather than patient interests / K. A. Tikkinen, A. Auvinen // European Urology. - 2012. - Vol. 61, Issue 4. P. 746-748. 
5. EAU Guidelineson Urinary Incontinence / J. W. Thüroff, P. Abrams, K.-E. Andersson // European Urology. - 2011. Vol. 59, Issue 3. - P. 387-400.

6. Nurko S. Coexistence of constipation and incontinence in children and adults / S. Nurko, S. M. Scott // Best Practice \& Research Clinical Gastroenterology. - 2011. - Vol. 25, No. 1.- P. 29-41.

\section{References}

1. Walden, A.L., Salsbury, S.A., Reed, W.R., \& Lawrence, D.J. (2014). Bladder and bowel symptoms among adults presenting with low back pain to an academic chiropractic clinic: results of a preliminary study. Journal of Chiropractic Medicine, 13 (3), 178-187.

2. Gormley, E.A., Lightner, D.J., \& Burgio, K.L. (2012). Diagnosis and treatment of overactive bladder (non-neurogenic) in adults: AUA/SUFU Guideline. The Journal of Urology, 188 (6), 2455-2463.

3. Gormley, E.A., Lightner, D.J., Faraday, M., \& Vasavada, S.P. (2015). Diagnosis and treatment of overactive bladder (nonneurogenic) in adults: AUA/SUFU Guideline Amendment. The Journal of Urology, 193 (5), 1572-1580.

4. Tikkinen, K.A., \& Auvinen, A. (2012). Does the imprecise definition of overactive bladder serve commercial rather than patient interests. European Urology, 61 (4), 746-748.

5. Thüroff, J.W., Abrams, P., \& Andersson, K.-E. (2011). EAU guidelineson urinary incontinence. European Urology, 59 (3), 387-400.

6. Nurko, S., \& Scott, S.M. (2011). Coexistence of constipation and incontinence in children and adults. Best Practice \& Research Clinical Gastroenterology, 25 (1), 29-41.

\section{ОЦЕНКА ПОКАЗАТЕЛЕЙ ЛАТЕНТНОГО ПЕРИОДА БУЛЬБОКАВЕРНОЗНОГО РЕФЛЕКСА И ЭЛЕКТРОМИОГРАФИИ В ДИАГНОСТИКЕ И ЛЕЧЕНИИ БОЛЬНЫХ С ПОВЫШЕННЫМ ТОНУСОМ НЕРВНО-МЫШЕЧНЫХ СТРУКТУР МОЧЕВОГО ПУЗЫРЯ И ДИСТАЛЬНЫХ ОТДЕЛОВ ТОЛСТОЙ КИШКИ ПО ГИПЕРКИНЕТИЧЕСКОМУ ТИПУ}

С.А. Возианов ${ }^{1}$ М.П. Захараш², П.В. Чабанов ${ }^{1}$ Ю.М. Захараш², Н.А. Севастьянова ${ }^{1}$, В.Ю. Угаров ${ }^{1}$, А.С. Репринцева ${ }^{3}$

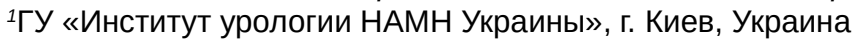

${ }^{2}$ Национальный медицинский университет имени А.А. Богомольца, г. Киев, Украина

${ }^{3}$ КНП «Центр первичной медико-санитарной помощи № 2» Соломенского района, г. Киев, Украина

Цель: повысить эффективность диагностики и лечения больных с повышенным тонусом нервномышечных структур мочевого пузыря и дистальных отделов толстой кишки по гиперкинетическому типу.

Материалы и методы. В группу исследования вошли 33 человека с сочетанной нейрогенной патологией нижних отделов мочевыводящей системы и нижних отделов толстой кишки. Диагностику фрункциональных нарушений мочевого пузыря и толстой кишки проводили с определением латентного периода бульбокавернозного ресрлекса под контролем электромиографии.

Результаты. Проведенные исследования позволили оценить показатели латентного периода бульбокавернозного рефлекса и электромиографии в диагностике больных с повышенным тонусом нервномышечных структур мочевого пузыря и дистальных отделов толстой кишки по гиперкинетическому типу. Данные электромиографических исследований позволили разработать и оптимизировать методы лечения в зависимости от тонуса нервно-мышечных структур нижних мочевых путей и дистальных отделов толстой кишки.

Выводы. Проведённое консервативное лечение пациентов с повышенным тонусом нервно-мышечных структур мочевого пузыря и дистальных отделов толстой кишки по гиперкинетическому типу с помощью электростимуляции по тормозной методике является эфрфективным, обеспечивает положительный эффект в $91,4 \%$ случаев.

КЛЮЧЕВЫЕ СЛОВА: нейрогенные расстройства мочеиспускания; нейрогенная дисфункция кишечника; детрузор; электромиография; бульбокавернозный рефлекс.

\section{EVALUATION OF INDICATORS OF THE LATENT PERIOD OF BULBOQUERONE REFLEX AND ELECTROMYOGRAPHY IN THE DIAGNOSIS AND TREATMENT OF PATIENTS WITH INCREASED TONUS OF NEUROMUSCULAR STRUCTURES OF THE BLADDER AND DISTAL COLONIES OF THE HYPERKINETIC TYPE}

S.O. Vozianov ${ }^{1}$, M.P. Zakharash ${ }^{2}$, P.V. Chabanov ${ }^{1}$, Yu.M. Zakharash ${ }^{2}$, N.A. Sevastianova ${ }^{1}$, V.Yu. Uharov ${ }^{1}$, A.S. Repryntseva ${ }^{3}$ ${ }^{1}$ Institute of Urology of NAMS of Ukraine, Kyiv, Ukraine

${ }^{2} \mathrm{O}$. Bohomolets National Medical University, Kyiv, Ukraine

${ }^{3}$ Center of Primary Healthcare Aid of Solomianskyi district, Kyiv, Ukraine

Purpose: improving the effectiveness of diagnosis and treatment of patients with increased tonus of neuromuscular structures of the bladder and distal colonies of the hyperkinetic type.

Materials and Methods. The study group included 33 individuals with a combined neurogenic pathology of the lower sections of the urinary system and the lower sections of the colon. Diagnosis of functional disorders of the 
bladder and colon was performed with the definition of the latent period of bulbo-cavernous reflex under the control of electromyography.

Results. The conducted studies allowed the evaluating the indicators of the latent period of bulbocavernous reflux and electromyography in the diagnosis of patients with increased tonus of the neuromuscular structures of the bladder and of the distal colonies of the hyperkinetic type. Data of electromyographic studies allowed the developing and optimize treatment methods depending on the tone of the neuromuscular structures of the lower urinary tract and distal colon.

Conclusions. Conductive conservative treatment of patients with increased tonus of the neuromuscular structures of the bladder and distal gastrointestinal segments of the hyperkinetic type by electrostimulation of the braking technique is effective, providing a positive effect in $91.4 \%$ of cases.

KEY WORDS: neurogenic disorders in urination; intestine neurogenic dysfunction; detrusor; uroflowmetry; electromyography; bulbocavernous reflex.

Рукопис надійшов до редакції 07.11.2017 p.

\section{Відомості про авторів:}

Возіанов Сергій Олександрович - член-кореспондент НАМН України, професор, доктор медичних наук, директор ДУ «Інститут урології НАМН України»; тел.: +38(044) 486-55-52.

Захараш Михайло Петрович - член-кореспондент НАМН України, доктор медичних наук, головний колопроктолог МОЗ України, заслужений лікар України, професор кафедри хірургії № 1 Національного медичного університету імені О.О. Богомольця; тел.: +38(044) 235-52-89.

Чабанов Павло Вікторович - кандидат медичних наук, завідувач лабораторії нейроурології дУ «Інститут урології НАМН України»; тел.: +38(044) 486-55-52.

Захараш Юрій Михайлович - доктор медичних наук, професор кафедри хірургії № 1 Національного медичного університету імені О.О. Богомольця; тел.: +38(044) 235-52-89.

Севастьянова Наталія Анатоліївна - кандидат медичних наук, провідний науковий співробітник лабораторії нейроурології ДУ «Інститут урології НАМН України»; тел.: +38(044) 486-55-52.

Угаров Володимир Юрійович - молодший науковий співробітник лабораторії нейроурології дУ «Інститут урології НАМН України»; тел.: +38(044) 486-55-52.

Репринцева Анастасія Святославівна - лікар загальної практики - сімейної медицини КНП «Центр первинної медико-соціальної допомоги № 2» Солом'янського району, м. Київ. 